\title{
Competency-Based Education And Shared Academic Freedom For Transformational Education
}

\author{
Helen Harris, Ed.D., MSW \\ Rob Rogers, Ph.D., MSW \\ Jon Singletary, Ph.D., MSW \\ Baylor University, USA
}

URL:http://dx.doi.org/10.19044/ejes.v3no3a1

\begin{abstract}
Curricular revision consistent with program mission and goals and that also fulfils accreditation requirements is essential for social work programs. In this article transformational education, shared academic freedom, and competency-based evaluation are described as central to effective preparation of students in social work education. The authors provide an overview of the transformational education literature and one school of social work's curricular revision process that demonstrates facultywide ownership of the revision process. The paper concludes with a discussion of how the faculty ownership and student evaluation process helped the school avoid the reductionist pitfalls in competency-based education in their pursuit of transformational education for programmatic impact.
\end{abstract}

Keywords: competency-based education, shared academic freedom, transformation

\section{Introduction:}

Transforming students into social workers who transform agencies, policies, communities, and sometimes the lives of clients is the lofty goal social work educators aspire to and the work to which they are committed. The profession joins the academy in this endeavor as social workers document the knowledge, skills, and values that are essential to their work and the academy designs curricula to prepare graduates to do the work. Professional education encompasses both the specificity of competencies of the profession and the critical thinking and broad learning of the academy.

This article provides an overview of a school of social work's curricular revision process devoted to transformational education, competency-based evaluation, and faculty-wide ownership of the revision 
process, that is, shared academic freedom. Included is a description of the concept of transformational education and an examination of our school's competency-based evaluation process along with descriptions of assessment tools, reports, and resulting changes. The paper concludes with a discussion of how this process helped the school avoid the reductionist pitfalls in competency-based education in the pursuit of transformational education. The integration of these concepts is not only possible; it is essential.

\section{One School's Journey:}

The School of Social Work (SSW) began with an undergraduate social work program more than 30 years ago and added an MSW program in the 1990s and a PhD program more recently. Since its inception, the School has been continuously accredited by the Council on Social Work Education (CSWE).

Multiple factors motivated the School's curriculum revisions. One was CSWE's shift in the focus of its Educational Policy and Accreditation Standards (EPAS) from essential content required for the education of social work professionals to professional competencies and practice behaviors operationalizing the competencies. The time was approaching for us to prepare a new self-study for reaffirmation of accreditation. This is part of a process that occurs every eight years for all social work programs during which they demonstrates that they meet current EPAS standards. Beyond adherence to the new standards for the explicit curriculum (courses) was a commitment to include our emphasis on the various ways faith is relevant to ethical social work practice. The ethical integration of faith in social work practice is central to our mission, and developing a curriculum congruent with it as well as our unique context of practice was essential. A final motivation was the challenge to remain competitive with several strong social work programs within 100 miles of our school and the emergence of online MSW programs nationwide.

\section{University Context:}

Concurrent with our curricular revision process, the university was engaged in developing a new strategic plan with a focus on excellence in higher education, specifically referred to as transformational education. The guiding document for the strategic plan states that the university desires to be a place "where academic excellence and life-changing experiences ignite leadership potential that increases our students' desire for wisdom, understanding of calling, and preparation for service in a diverse and interconnected global society” (Pro Futuris, 2012).

Consistent with the mission of the university and the school, faculty members agreed on the importance of recognizing that students choose to 
become social workers due to a sense of calling to respond to the needs of a hurting world. Their education includes both the course work (explicit curriculum) and their interactions with faculty, speakers, and the practice community (implicit curriculum); these are the vehicles for equipping them to respond to that call, making curricular change central to the accomplishing the mission of the school and the university. The faculty's role includes developing curricula that equip students with a professional identity and professional knowledge, values, and skills, as well as quantifying and measuring educational and professional practice outcomes.

\section{Literature Review:}

The primary concepts driving curriculum revision in our school of social work were shared academic freedom, transformational education, and competency-based education, that is, the move from a content-based curriculum to one based in practice competencies. This literature review examines these three concepts.

\section{Shared Academic Freedom:}

Academic freedom has been an important concept in higher education since the early 1900s coming from the German concept of lehrfreiheit, or the freedom of teachers (Champagne, 2011). Much that is written about academic freedom implies an adversarial position between faculty and administration in higher education. Academic freedom is discussed in terms of shared governance and the assumption that faculty must contend for their right to teach what they understand to be truth and for the discovery of knowledge (AAUP, 2008). The literature is almost silent in describing academic freedom as a shared or collaborative element in the university setting.

Poore (2009) discussed the institution's duty and right to hold faculty members accountable for engaging in professional development that would improve their ability to teach and produce positive student outcomes. The assumption is that the role and intent is adversarial rather than that faculty would be motivated to improve student outcomes. The author wondered if the "principles of academic freedom give the faculty total control over how they design and teach their courses" (p. 2). Champagne (2012) identified academic freedom as curriculum control including both course design and course content. This freedom is identified as an individual concept.

The national On-Campus Report (2005) included the importance of cooperation in academic freedom. The author discussed this in terms of requiring collaboration rather than assuming that faculty would be invested in and supportive of collaboration. Further, Champagne (2011) suggested 
that assessment of learning outcomes is "an attack on academic freedom” (p. 9).

Within our School, a culture of collegiality and mutual support provided a foundation for our faculty's adoption of the concept of shared academic freedom. This concept includes a belief that our integrated effort is stronger than simply adding courses together and that the curriculum is strongest when courses build on each other and when there is a coordinated inclusion of theory and practice models with common language both in the school and in the practicum community. We considered practice behaviors and textbooks and assignments that result in knowledge and skill growth and development in a coordinated effort. We coined a new term for this concept: shared academic freedom. We recognized our joint responsibility for a coherent curriculum that allows students to build knowledge and skill balanced with continued individual academic freedom in our courses. Full and part-time faculty members shared not only in making decisions about the curriculum but also in collaborating on course planning and delivery. This approach kept the mutual focus of both faculty members and administrators on curricular rather than control issues. In addition, our joint ownership of the process released creative energies that transcended any sense that we were merely acting out of obligation to adhere to the new accreditation standards.

\section{Competency-based Education:}

The movement to competency-based education began in vocational education and training more than 40 years ago (Malone \& Supri, 2012). These authors expressed concerns about the adoption of a competency-based curriculum in medical education. Important questions included: Is there a loss of overall competence by focusing on smaller units like practice behaviors? What is the impact on the content of the curriculum and the narrowing of focus? Reeves, Fox, and Hodges (2009) found that "the creation of competencies may also be regarded as an effort by professions to define certain activities that 'belong' to them” (p. 452).

Hodkinson (1992) discussed two models of competence, behavioristic and interactive, noting that professional schools in the Academy are sometimes drawn to skill acquisition. Hodkinson recommended that an interactive model of competence is more effective for developing thinking and conceptual learning. The interface of knowledge and understanding with practical professional skills provides a model for adapting competencies in a variety of contexts (Ashworth, 1992). The author noted that this higher-level thinking is difficult to assess and requires that competency-based assessment include attention to reliability and validity. 
The importance of field education to social work education is a central factor in competency-based social work instruction. Field instructors and field agencies articulate what knowledge and skills are required for social workers in practice. Evaluating those in students is a significant opportunity and challenge. "While social work educators use a range of methods to assess student learning and program outcomes, a recurring theme is the difficulty of evaluating field learning” (Bogo, et al., 2006). Field instructors are increasingly involved in our curriculum meetings and other committee work to address their preparation for teaching and assessing our students. Classroom faculty and field instructors, whom we call field faculty, collaborate on defining and operationalizing practice behaviors in specific field contexts. Individual learning contracts are tailored to identify practice behaviors in agencies and student evaluation is based on the provision of evidence of practice behavior skill demonstration.

\section{Transformational Education:}

Our private university has adopted transformational education as one of the centerpieces of its strategic vision. The standardization of education and outcomes does not address who and what is being transformed and to what end. Powell (2011) reminded faculty and administration that the best assessment of transformation or change as a result of education is not comparison with others or with an arbitrary standard, but with oneself and is longitudinal and understood over time. Helping students, faculty, and organizations identify who and what they aspire to be also provides the opportunity to document change and progress toward that end. This reinforces the importance of mission and of student calling.

Palmer (2014) reports that transformational education begins with transforming the institution into a place of respect rather than fear. "If we could reclaim the sacred - simple respect - in education, how would it transform our knowing, teaching, and learning? (Palmer, 2016, p. 6). Transformational education is the essence of our mission and of the calling of our students to serve the sacred and make a difference to individuals and the systems they live in. This perspective has motivated our school's ongoing efforts to define the term impact and determine how to measure not only the impact of the program on students and alumni but also their impact on the communities where they work. Furthermore, faculty members are examining how to assess the impact of their research and service as well as their teaching. This multifaceted process has challenged our assumptions about what is of lasting significance and who needs to be involved in making this judgment and gauging how well it is being achieved. 


\section{The Caution of Virtue Ethics:}

Along with struggle to revise standards of excellence, the convergence and interface of competency-based education and transformational education presents the challenge of trying to maximize multiple values at the same time. In addition, the shift in social work to competency-based education, the enhanced role of field education as the signature pedagogy, and the business model of preparing students for the work environment raises the concern that we not replace robust education with training. Historically, social work is grounded in the liberal arts to ensure the development of critical thinking, understanding of systems, and commitment to social justice.

Chamiec-Case (2012) cautioned that the complexity of the profession of social work calls for social work educators to avoid marginalizing values and ethics by separating knowledge and skills from values and beliefs. The author expressed concern that memorized strategies and rote skills rather than critical thinking and professional judgment are not enough when engaging change in human lives. The author offered virtue ethics as a paradigm that includes character and virtue in professional development and professional behavior. The development of character and virtue is congruent with transformational education and minimizes the danger of focusing on competencies without commensurate attention to the art of becoming genuine and authentic helpers.

Moving beyond outcome-based education that is focused solely on competencies to an educational experience that is transformational requires a faculty fully engaged in making sense of these new concepts and how to apply them to our curriculum. To help us understand what transformational education means in our educational setting, we began to consider a series of questions:

- What transformation are students seeking?

- What transformation do we seek for them?

- What learning experiences will facilitate transformation?

- How will we know when and to what degree transformation has occurred?

- How will others know?

\section{The Transformational Curricular Process:}

Before considering a list of competencies, the faculty participated in a daylong appreciative inquiry retreat (Cooperrider \& Whitney, 2005) that focused on visioning the future of social work education in our school. The theme of the retreat was expressed in our unofficial motto of wanting the education of our students to be REAL: Reflective, Experiential, Authentic 
Learning. The values embedded in this acronym continue to shape our process of curricular innovation toward transformation.

The REAL acronym captured the commitment of the faculty to curricular revision that would include transformation for faculty as well as for students. The "R" in REAL emphasized education characterized by selfawareness, critical thinking, and collegial and collaborative work. The importance of the practice components of the curriculum and the centrality of the field internship program were expressed with " $E$ " for Experiential learning. This focus on field education and the importance of student demonstration of competencies with actual clients and projects set our program on a course congruent with the profession's concept of field education as the signature pedagogy. Further, the MSW program curriculum included experiential learning in research through the completion of a practice-based research project during the final year of the MSW curriculum.

The " $A$ " in REAL refers to the centrality of Authenticity throughout the educational process. This quality is manifested in relationships of mutual respect, valuing listening more than advocacy, engaging those we serve in crafting solutions, and debating questions that matter. The result is a healthy community that is connected to the mission and goals of our university and school, the unique calling and gifting of our students and faculty, and the needs and resources in the communities in which we and our students work. Finally, curricular change grounded in being intentionally reflective, experiential, and authentic created a dynamic environment of Learning, the "L", that concentrates not only on monitoring processes and measuring outcomes but also on assessing learning, growth, and impact over time.

Our school made program revisions based on our REAL Retreat and integrated our changes with the stated goal of the competency-based EPAS, addressing academic excellence through the lens of professional competence. The result is a curriculum that exemplifies the co-inherence of 1) EPAS Core Competencies and Practice Behaviors; 2) the school's own mission, goals, objectives, and themes of community building, strengths perspective and the ethical integration of faith and practice; 3) explicit generalist and advanced curricula; and 4) an implicit curriculum that emphasizes our university's religious and regional context. We created an evaluation system for our generalist and advanced educational outcomes that included both rubrics to assess the attainment of practice behaviors in classroom and field courses, and surveys for students to assess their self-efficacy with respect to the practice behaviors.

Curricular revision for transformational education required investment and ownership by the entire faculty rather than a representative sample on a curriculum committee. The entire faculty decided to meet weekly as a curriculum committee to assure curricular integration and 
synthesis. During two years of operating as a curriculum committee of the whole, our understanding of academic freedom expanded to include a shared or communal component as well as the traditional individual elements. Together we designed the overall curricular structure for the BSW and MSW program; identified course goals and objectives; made decisions about core courses, groupings of courses, and the three concentrations related to advanced practice in the MSW program; built the scaffolding of educational competencies that linked one course to the next; and addressed field education opportunities and challenges.

An additional benefit from collaborative decision making was the clear alignment of program mission, goals and objectives with individual course objectives and across vertical and horizontal intersections in the curriculum. Vertical intersections included those course sequences that build on one another across time, e.g. Practice I to Practice II to Practice III. Another example is the multi-year research sequence that includes statistics, research, and the research project. Horizontal intersections included courses that were taken in tandem with one another in the same semester, such as Human Behavior and the Social Environment I and Practice I.

\section{Alignment toward Transformational Education:}

Although we adopted the competencies and practice behaviors of the accrediting agency, we also added an additional competency and related practice behaviors specific to a core theme of our school: the ethical integration of faith and practice. This competency was integrated, along with the others, into major content areas including human behavior, values and ethics, diversity, practice, policy, and field education. For example, in field education we considered contexts of practice for the ethical integration of faith and practice to include congregations and religiously affiliated organizations where students could demonstrate all of the educational competencies and related practice behaviors. Bringing social work students and experienced field instructors into these contexts was not only transformative for the students but for the practice settings and their communities as well (Harris, Yancey \& Myers, 2016).

\section{Accountability:}

The complex curriculum required an intricate method to track student learning. We first created a master planning spreadsheet for each program showing the alignment of program goals, course objectives, and competencies. After examining each course's content, readings, speakers, and assignments, faculty members decided where to place the individual practice behaviors and how to assess them. Such detailed alignments are 
essential for a coherent evaluation of student learning in which students must demonstrate their mastery of the competencies and practice behaviors.

The next step was the development of rubrics designed to evaluate the program by assessing student competence through their demonstration of the practice behaviors. Faculty members designed a rubric for each assignment that measures practice behaviors. For our purposes rubrics are the tools we use to communicate more clearly to students and to ourselves as faculty members expectations about the essential learning in each assignment, and to provide feedback to students about how well they are learning and how well we as professors are teaching. Faculty must make complex judgments when assessing student demonstration of competence in assignments. These rubrics are constructed and designed to provide a grounded basis for those judgments.

Currently instructors use the rubrics to assess only the practice behaviors related to the assignment. We continue to explore how to use them to grade assignments, because grading includes elements beyond the scope of the practice behaviors, such as additional content, writing skills, and the use of APA style.

The example in Figure 1 is a rubric for a portfolio assignment in the BSW Senior

Capstone course.

Figure 1. Rubric for BSW Capstone Research Assignment.

\begin{tabular}{|c|c|c|c|c|c|}
\hline \multicolumn{6}{|c|}{ School of Social Work } \\
\hline \multicolumn{6}{|c|}{ Individual Grading Rubric } \\
\hline \multicolumn{6}{|c|}{ SWO 4293 - Senior Capstone Seminar } \\
\hline \multicolumn{6}{|l|}{ Student: } \\
\hline \multicolumn{6}{|c|}{ Capstone Rubric } \\
\hline \multirow{3}{*}{$\begin{array}{l}\text { Practice } \\
\text { Behaviors } \\
\text { and Other } \\
\text { Criteria }\end{array}$} & 1-Inadequate & 2-Novice & $\begin{array}{l}\text { 3- } \\
\text { Competent }\end{array}$ & 4-Proficient & 5-Excellent \\
\hline & $\begin{array}{l}\text { Doesn't } \\
\text { demonstrate } \\
\text { it }\end{array}$ & $\begin{array}{l}\text { Demonstrate } \\
\mathrm{s} \text { it somewhat }\end{array}$ & $\begin{array}{l}\text { Demonstrat } \\
\text { es it okay }\end{array}$ & $\begin{array}{l}\text { Demonstrat } \\
\text { es it well }\end{array}$ & $\begin{array}{l}\text { Demonstrat } \\
\text { es it very } \\
\text { well }\end{array}$ \\
\hline & $<\mathbf{8 0}$ & 80-82 & 83-86 & 87-89 & $90-100$ \\
\hline \multicolumn{6}{|l|}{$\begin{array}{l}6.1 \quad \text { Use } \\
\text { practice } \\
\text { experience to } \\
\text { inform } \\
\text { scientific } \\
\text { inquiry } \\
\end{array}$} \\
\hline $\begin{array}{lr}6.2 & \text { Use } \\
\text { research } & \\
\text { evidence } & \text { to } \\
\text { inform } & \\
\text { practice. } & \end{array}$ & & & & & \\
\hline
\end{tabular}


It measures the two practice behaviors in the EPAS research competency, which are to engage in research-informed practice and practiceinformed research. The 5-point scale goes from 1 "Inadequate - does not demonstrate competence" to "2-Novice", "3-Competent", "4-Proficient”, and finally to "5-Excellent - demonstrates commendable competency." The $100 \%$ grading scale has been apportioned to correspond to the 5-point competency scale. Anything below $80 \%$ (grade of B-) is considered inadequate from a competency standpoint. An A- (90\%) is considered excellent in this rubric. When grading an assignment, professors can place an $\mathrm{X}$ in a cell based on the actual grade the student has earned for a particular practice behavior, or they can refer to the 5-point scale and place an " $X$ " in a cell based on a student's grade and their professional judgment about the student's competence.

The rubrics, completed at the end of each semester, are compiled and analyzed with findings made available in Course and Program-level Outcome Reports. Figure 2 is a facsimile of a Course Outcome Report for a rubric that measured the competency related to research. The competency has two practice behaviors, and for this course the report shows the number of students (27), the average score for each practice behavior $(4.04,3.96)$, and the distribution of scores across the five-point scale (count and percent).

Figure 2. Course Outcome Report

\begin{tabular}{|c|c|c|c|c|c|c|c|c|c|c|c|c|c|}
\hline \multicolumn{14}{|c|}{\begin{tabular}{l|l}
\multicolumn{2}{|l|}{ Performance by Standards Report } \\
Report:
\end{tabular}} \\
\hline & & \multicolumn{12}{|c|}{ Report Generated by TaskStream } \\
\hline \multicolumn{2}{|c|}{ DFR Template(s): } & \multicolumn{12}{|c|}{ BSW Spring 2012} \\
\hline \multicolumn{2}{|l|}{ Program(s): } & \multicolumn{12}{|c|}{ BSW Spring 2012} \\
\hline \multicolumn{2}{|l|}{ \# Authors } & \multicolumn{12}{|c|}{132 Authors matched search criteria } \\
\hline \multicolumn{2}{|c|}{ Report Generated: } & \multicolumn{12}{|c|}{ Sunday, September 30, 2012} \\
\hline \multicolumn{14}{|c|}{ Competency 6. Engage in research-informed practice and practice -informed research } \\
\hline $\begin{array}{l}\text { Rubric } \\
\text { Criteria }\end{array}$ & $\begin{array}{l}\text { Authors } \\
\text { Evaluat } \\
\text { ed }\end{array}$ & $\begin{array}{l}\text { Results } \\
\text { for } \\
\text { Group }\end{array}$ & \multicolumn{11}{|c|}{ Distribution of Scores } \\
\hline \multirow[b]{2}{*}{$\begin{array}{l}\text { G6.1 Use } \\
\text { practice } \\
\text { experience to } \\
\text { inform } \\
\text { scientific } \\
\text { inquiry } \\
\text { Folio Area: } \\
4293 \text { Senior } \\
\text { Capstone } \\
\text { Seminar } \\
\text { DFR } \\
\text { Template: } \\
\text { BSW Spring } \\
\text { 2012 }\end{array}$} & \multirow{2}{*}{$\begin{array}{l}27 \quad \text { of } \\
132 \\
(20.45 \% \\
)\end{array}$} & \multirow{2}{*}{$\begin{array}{l}\text { Ave. = } \\
4.04 / 5 \\
(80.8 \% \\
)\end{array}$} & $\begin{array}{l}\text { Sco } \\
\text { re }\end{array}$ & 1 & & 2 & & 3 & & 4 & & 5 & \\
\hline & & & $\begin{array}{l}\text { Cou } \\
\text { nt/ } \\
\%\end{array}$ & 0 & $\begin{array}{l}0 \\
\%\end{array}$ & 0 & $\begin{array}{l}0 \\
\%\end{array}$ & $\begin{array}{l}1 \\
0\end{array}$ & $\begin{array}{l}37.0 \\
4 \%\end{array}$ & 6 & $\begin{array}{l}22.2 \\
2 \%\end{array}$ & 11 & $\begin{array}{l}40.7 \\
4 \%\end{array}$ \\
\hline $\begin{array}{ll}\text { G6.2 } & \text { Use } \\
\text { research } & \end{array}$ & $\begin{array}{ll}27 & \text { of } \\
132\end{array}$ & $\begin{array}{l}\text { Ave. }= \\
3.96 / 5\end{array}$ & $\begin{array}{l}\text { Sco } \\
\text { re }\end{array}$ & 1 & & 2 & & 3 & & 4 & & 5 & \\
\hline
\end{tabular}




\begin{tabular}{|c|c|c|c|c|c|c|c|c|c|c|c|c|c|}
\hline $\begin{array}{l}\text { evidence to } \\
\text { inform } \\
\text { practice } \\
\text { Folio Area: } \\
4293 \text { Senior } \\
\text { Capstone } \\
\text { Seminar } \\
\text { DFR } \\
\text { Template: } \\
\text { BSW Spring } \\
2012\end{array}$ & $\begin{array}{l}(20.45 \% \\
)\end{array}$ & $\begin{array}{l}(79.2 \% \\
)\end{array}$ & $\begin{array}{l}\text { Cou } \\
\text { nt/ } \\
\%\end{array}$ & 0 & $\begin{array}{l}0 \\
\%\end{array}$ & 0 & $\begin{array}{l}0 \\
\%\end{array}$ & $\begin{array}{l}1 \\
0\end{array}$ & $\begin{array}{l}37.0 \\
4 \%\end{array}$ & 8 & $\begin{array}{l}29.6 \\
3 \%\end{array}$ & 9 & $\begin{array}{l}33.3 \\
3 \%\end{array}$ \\
\hline $\begin{array}{l}\text { Average of } \\
\text { all scores in } \\
\text { group }(n=54)\end{array}$ & & $\begin{array}{l}4.00 / 5 \\
(60.00 \\
\%)\end{array}$ & & & & & & & & & & & \\
\hline $\begin{array}{l}\text { Average for } \\
\text { all scores } \\
(\mathrm{N}=54)\end{array}$ & & $\begin{array}{l}43.20 / 5 \\
4 \\
(80.00 \\
\%)\end{array}$ & & & & & & & & & & & \\
\hline
\end{tabular}

In addition to instructors using the rubrics to assess students, the faculty designed a process for student self-assessment. Students assess their own levels of competence at the beginning and end of each academic year in the program by completing a self-efficacy scale of the practice behaviors.

Table 1 is an excerpt from a program-level report showing the average competency and practice behavior ratings for the 27 students for three competencies (research, human behavior, and policy) assessed by professors in their Field Education and Capstone courses, and by students themselves on the Self-efficacy scale.

Table 1: BSW Generalist Competencies and Practice Behaviors: Summary 2011-12

\begin{tabular}{|ccll|}
\hline $\begin{array}{l}\text { Competencies \& } \\
\text { Practice Behaviors }\end{array}$ & Field & Capstone & $\begin{array}{l}\text { Student } \\
\text { Self-Efficacy }\end{array}$ \\
\hline G6-Research & 3.39 & 4.00 & 3.61 \\
G6.1 & 3.77 & 4.04 & 3.45 \\
G6.2 & 3.00 & 3.96 & 3.77 \\
G7-Behavior & 4.31 & 4.63 & 3.97 \\
G7.1 & 3.92 & 4.63 & 3.77 \\
G7.2 & 4.65 & 4.63 & 4.16 \\
G8-Policy & 4.16 & 4.04 & 3.60 \\
G8.1 & 3.77 & 4.00 & 3.52 \\
G8.2 & 4.27 & 4.07 & 3.68 \\
\hline
\end{tabular}

At the competency level the most notable difference among the three assessments is that the student self-efficacy scores are lower than the faculty ratings except the field score for the research competency. The students perceive themselves to be competent (between 3.61-3.97/5) but less so than their professors who rated them almost entirely in the proficient range (4.004.63/5). The exception is the research competency where the field faculty score of 3.39 is lower than the students' rating of 3.61. Why do students not 
perceive themselves as competent as their professors do? That is an issue faculty and students have begun to discuss.

Table 1 also displays the scores for six practice behaviors - two each for the research, human behavior, and policy competencies. At this more detailed level we see again that students perceive themselves as less competent than their professors do with one notable exception. For research practice behavior "G6.2 - Use research evidence to inform practice", the field seminar professors rated the students 3.0, barely competent (almost at the novice level). The concern is that students demonstrated in their Capstone portfolio that they can appropriately integrate research and practice, but they may not be using evidence-informed practices in their actual work in the field. A possible explanation for this discrepancy is that students selected for their portfolios examples from papers in courses where there was research related to practice, but in their internship the situations they had to address were ones without research evidence to guide their practice or existing evidence was overlooked.

Examining learning at the level of practice behaviors and from multiple perspectives has provided us with a nuanced view of outcomes and highlighted issues we could not have identified otherwise. Concerns like the two mentioned above are being examined by our faculty, field supervisors, and students. In addition, our faculty is striving to improve inter-rater reliability when assessing the competencies and also examining the measures we use to help ensure their validity.

\section{Connecting Evaluation to Transformation:}

These evaluation results facilitated conversation about how social work research, including the use of evidence-based practices and the evaluation of practice, can be implemented more systematically within practice settings and in a wider range of settings. Focusing attention on best practices and evaluating practice results can be transformational for both student interns and staff. The next logical and challenging step is to assess transformation in those who receive the services provided by students and agencies.

\section{Implications:}

Faculty members engaging with each other in an atmosphere shared academic freedom are able to pursue transformational education that contributes to achieving competence as well as to measuring and improving outputs in academic programs and affiliated agencies. This focus on competency-based education is enriched by shared academic freedom with the intent to produce a coordinated curriculum for student transformation. We are beginning conversations about how this pursuit will help us 
understand the impact of our program to transform graduates and communities as well.

\section{Shared Academic Freedom:}

The curricular development and enrichment process is the responsibility of the entire faculty whose ownership and participation make substantive and sustainable change possible. The process we undertook was stimulated by but not primarily in response to the external demands of accreditation. It was motivated by a desire for proactive innovation consistent with our mission and goals and with internal program accountability for transformation. As we shared responsibility for the curriculum, we shared in the assessment and celebration of transformation. The vehicle for curricular enrichment and innovation was the combination of shared academic freedom and a competency-based educational model. The approach included commitment to both explicit and implicit curricular change rooted in a collaborative overhaul of the curricula and an intentional evaluation of students' practice behaviors in the classroom and in the field. It also included the students' self-assessment of their competence. The results? Students report the transformation of their own practice skills and intentional professional identity; agencies report the transformation of services offered in their settings as students bring cutting edge practices to the facilities; and faculty report an infusion of energy and a clarity of purpose in teaching a curriculum that is designed to produce and measure growth and change. Student course evaluations and field performance supported these reports of transformation. Further, faculty and administrators reported increased collegiality with their joint focus on curricular change and student outcomes. These results indicate transformation instead of the pitfall of simply focusing on competency scores.

\section{Limitations:}

One significant limitation is that our evaluation method that does not measure change in agencies and in their service populations. Faculty and students on the curriculum and the evaluation and accreditation committees are responsible for defining impact and monitoring the impact of our educational programs. It will be important to include agency constituencies in that committee work. Another limitation is that the evaluation system is designed to examine program-level outcomes only. It is not designed to track the development of the competence of individual students as they progress through the program. We are striving to improve both inter-rater reliability and the validity of our measures before directing our attention to the level of tracking individual student progress in the program. 


\section{The Goal of Transformational Education-Impact:}

The profession's move from evaluating educational programs by their input of content to their outcomes of competence in practice behaviors was a major paradigm shift. Viewing this shift in light of transformational education pushes the boundaries even further by raising the critical issue of the impact of what students learn. Therefore, in addition to including content on character and virtue and focusing on behavioral outcomes, we have also begun to expand the core question for our program evaluation from "What are the average practice behavior scores of our students?" to "What difference does our social work education make in the life of a student helper?" What difference does it make to have social work students and supervising faculty in agencies, including congregations and RAOs? What is the impact of social work provided by students on the lives of those served by those agencies? Furthermore, we are asking: "What differences are social work faculty members making in society's understanding of the human condition, the challenges of injustice, the changes in technology and education delivery, and international education? Where are our graduates making a difference in the lives of others both locally and globally? What is being transformed inside us and around us, and to what end?" These are the questions that will lead us to understanding the impact of our program. We are at the beginning of the process informed by our shared academic freedom and our commitment to professional competence.

\section{Conclusion:}

Social work education, which prepares students to be change agents, finds itself in the position of being a change agent for transformation in higher education and, beyond that, in the communities in which we serve. We assert that our development of shared academic freedom in a curricular change process focused on competency-based education is the path to transformation in students and graduates. While accrediting processes matter, they are not the driving motivation for curricular change. The opportunity to collaborate together for transformation for our students and graduates resulted in transformation in the faculty as well.

\section{References:}

AAUP. (2008a). Academic freedom. In 1940 Statement of Principles on Academic Freedom and Tenure. Retrieved November 27, 2008 from http://www.aaup.org/AAUP/pubsres/policydocs/contents/1940statement.htm AAUP. (2008b). The statement. In Statement of Professional Ethics. Retrieved November 27, 2008 from http://www.aaup.org/AAUP/pubsres/policydocs/contents/statementonprofess ionalethics.htm 
Ashworth, P. (1992). Being competent and having 'competencies'. Journal of Further and Higher Education, 16(3), 9-17.

Baylor University. (2012). Pro Futuris. Waco, Texas: Author.

Bogo, M., Regehr, C., Woodford, M., Hughes, J., Power, R., \& Regehr, G. (2006).

Beyond competencies: Field instructors' descriptions of student performance. Journal of Social Work Education, 42(3), 579-593.

Champagne, J. (2011). Teaching in the corporate university: Assessment as a labor issue.

AAUP Journal of Academic Freedom, 2, 1-26.

Harris, H., Yancey, G., \& Myers, D. (2016). Social work field education in and with congregations and religiously-affiliated organizations in a Christian context. Journals, 7(x). doi-10.3290; www.mdpi./journal/religions

Harris, H., Rogers, R., \& Singletary, J. (2013, November). Curricular Revision, Evaluation, and Reaffirmation. Paper presented at the Council on Social Work Education Annual Program Meeting. Dallas TX.

Hodkinson, P. (1992). Alternative models of competence in vocational education and training. Journal of Further and Higher Education, 16(2), 3039.

Malone, K. \& Supri, S. (2012). A critical time for medical education: The perils of competence-based reform of the curriculum. Advances in Health Sciences Education, 17, 241-246. Doi 10.1007/s10459-010-9247-2

Palmer, P. (2016). The grace of great things: Reclaiming the sacred in teaching, knowing, and learning. Retrieved on June 15, 2016.

http://www.couragerenewal.org/PDFs/Parker-Palmer_The-Grace-of-GreatThings.pdf

Pavela, G. (2005). Balancing student-faculty academic freedom. National On-Campus Report. Magna Publications, Inc., 33(21), 1-6.

Poore, Pariseau, C. (2009). Should faculty members be exempt from a mandate to receive instructional design training because of their rights under academic freedom? Journal of Academic Ethics 7, 223-230. DOI 10.1007/s10825-019-9073-4.

Powell, J. W. (2011). Outcomes assessment: Conceptual and other problems. AAUP Journal of Academic Freedom, (2).

Reeves, S., Fox, A., \& Hodges, B. (2009). The competency movement in the health professions: Ensuring consistent standards or reproducing conventional domains of practice? Advances in health Sciences Education 14, 451-453. 